Stavytskyy, A., Kharlamova, G., Giedraitis, V., \& Šumskis, V. (2018). Estimating

the interrelation between energy security and macroeconomic factors in

European countries. Journal of International Studies, 11(3), 217-238.

doi:10.14254/2071-8330.2018/11-3/18

of International
Studies

\title{
Estimating the interrelation between energy security and macroeconomic factors in European countries
}

\author{
Andriy Stavytskyy \\ Department of Economic Cybernetics, \\ Taras Shevchenko University of Kyiv \\ Ukraine \\ a.stavytskyy@gmail.com
}

\section{Ganna Kharlamova}

Department of economic cybernetics, Taras Shevchenko University of Kyiv

Ukraine

akharlamova@ukr.net

\section{Vincentas Giedraitis}

Vilnius University,

Lithuania

vincasgiedraitis@icloud.com

\section{Vaidotas Šumskis}

Lietuvos bankas,

Lithuania

vaidotas.sumskis@gmail.com

Abstract. This paper deals with the analysis of energy security in certain European countries. The investigation of different approaches to evaluation of the energy security parameter showed some drawbacks of their application in practice. This fact has led the authors to the idea to develop a completely new index of energy security that includes, inter alia, quite a traditional approach - based on the data about consumption, production, distribution, and allocation of energy resources - also paying attention to productivity and efficiency of using such resources. The first part of the paper discusses the advantages of a new parameter in comparison to the existing analogies. The next part concerns the estimation of four-panel regressions that describe the interrelation of main macroeconomic parameters with the new energy security index (NESI). They showed that the increase of GDP is positively correlated with NESI, and negatively - with CPI. Therefore, on the one hand, economic tools may improve energy security in Europe, and on 
the other, guaranteeing energy security leads to lower prices and bigger national output.

Keywords: energy security, index, panel regression, energy policy, macroeconomics, Europe.

JEL Classification: Q3, Q43, Q48

\section{INTRODUCTION}

Supply of energy is a vital part and a significant share of production processes, from energy-intensive industries to services. Uninterrupted energy supply is necessary to ensure the functioning of transportation systems and maintenance of critical IT and communication networks. Furthermore, energy costs are an important contributor to production costs in every business basically, especially for manufacturing companies where energy-related costs make around one-fifth of the total costs (CEPS, 2016). Consequently, the whole economy may be affected by the risks stemming from energy supply, when temporary or in some cases permanent energy supply shocks occur.

In terms of energy security, European countries are significantly heterogeneous, affected by natural, technological or, in some occasions, geopolitical or regulatory restraints. However, recent energy supply forecasts suggest the increasing dependency on imported energy in the common EU energy resources market for the medium term (Chernyak et al., 2018). For example, it is projected that imported gas will cover up to 80 percent of the total European Union's gas consumption by 2030 (Dreyer \& Stang, 2013). On the other hand, an increasing share of renewable energy production may partially offset the negative effects of the increased net imports. Nevertheless, it is still unclear what potential impacts these two energy consumption trends will have on the energy security in the foreseeable future as there is a variety of energy security evaluation methods which produce a wide range of estimates (Kharlamova et al., 2016).

Moreover, it is unclear whether governments can influence the energy security level through their budget and monetary policies. It would be necessary to determine how the energy security level is connected to the main macroeconomic parameters of countries. This analysis may help in the development of better government policies. The supply of energy along with its consumption structure may also influence the pollution level in countries that may shift climate conditions and therefore budget policies (Stavytskyy et al., 2016).

This research has two main objectives. The first one is to present a new energy security index, which thoroughly describes the real threats and possibilities of European countries in terms of energy security. The next objective is to analyze how this index is correlated with the main macroeconomic indicators in different European countries (Simionescu et al., 2017, Lazányi et al., 2017).

This paper is structured in the following way. The literature review represents the critical observation of scientific approaches that were used to measure the energy security before. The third part is dedicated to the introduction of a new index and its application in European countries. The fourth section represents data, which was used to calculate the energy security index. The fifth section explains the methodology behind the panel regressions along with a newly introduced energy security index. The next chapter represents the results obtained and the discussion. The final section provides conclusions. 


\section{LITERATURE REVIEW}

A wide variety of approaches towards energy security has been always prevailing. Consequently, various metrics produce different results and interpretations. Thus, the analyses of energy security and further energy policy developing became increasingly difficult (Mačerinskienė \& Kremer - Matyškevič, 2017; Štreimikienè et al., 2016).

Various authorities responsible for energy policy implementation have defined energy security as a concept. World Energy Council (2017) calculates the World Energy Trilemma Index. Energy security is one of the key elements of the composite index, equally weighted to energy equity and environmental sustainability. Energy security is defined as a measure of the ability to meet current and future demand. Such ability is estimated by the equally weighting diversity of primary energy supply, energy consumption in relation to GDP growth, import dependence, diversity of electricity generation, energy storage capability and preparedness for energy shocks. (Kasperowicz \& Štreimikienè, 2016). International Energy Agency (2007) has constructed two energy security indices, both of which are focused on explaining the reasons behind energy insecurity. The first index (ESIPrice) evaluates energy prices as a source of energy insecurity. While the second one (ESIVolume) estimates energy security level based on the physical availability of energy sources. ESIPrice index is calculated as Hirshman-Herfindahl index (the HHI index) and measures the market concentration of energy suppliers. The ESIVolume index is based only on imported gas share in total primary energy supply. Furthermore, only imported gas volumes with oil-indexed price contracts and pipeline-based transportation schemes are accounted. The higher is the share of imported gas, the less secure is the country's gas supply. The ESIPrice index is dedicated mostly for competitive energy market structures with a high degree of liberalization, where a sufficient number of energy suppliers compete for their market share. On the contrary, the ESIVolume index is applied in closely regulated energy markets where existing gas pipeline infrastructure hinders flexible choice of gas suppliers.

In contrast, the Energy security index estimated by the Institute for 21st Century Energy (2016) evaluates the energy security level and its dynamics in different countries by assessing 29 variables that belong to eight different categories: reliability and diversity of energy supplies and reserves; import dependency; expenditures on energy; vulnerabilities to energy prices and market volatility; intensity of energy use; reliability of electricity generation capacity; efficiency of energy use in transport sector, and exposure to international commitments on reduction of the greenhouse gas emissions (Chen et al., 2018; Vovk, 2016).

Multiple scientists have extensively researched the energy security. One of the academic works that encompasses multiple variables to derive an energy security index is Scheepers et al. (2007). It suggests a composite Supply/Demand index for evaluating the level of energy supply security. The index analyzes the whole spectrum of energy economics, including demand, transport sector needs and energy conversion. Augutis et al. (2011) produces an energy security evaluation scale for an assessment of energy supply security level. This methodology includes a number of economic, technical and socio-political variables. These variable blocks are further divided into smaller groups of variables within every block. Weights used to derive an energy security level within a scale are equal for every block and every variable in its group. Whereas, weights for variable groups have to be calculated separately (with the exception for socio-political block where group weights are equal).

Having in mind that the energy security is an interdisciplinary concept, Jun et al (2009), Harčariková \& Šoltés (2016) Chuang \& Ma (2013), Franki \& Višković (2015), Androniceanu \& Popescu, (2017) etc. considered the definitions as the vulnerable to exploitation by way of a justification for energy policy instruments. The extensive literature has not yet converged a unified definition of energy security. There is a multitude of methods of energy security measurement, such as the Supply/Demand index, the HirshmanHerfindahl Index, the Shannon Index for fuel diversity, and others. However, most of these indexing 
methods do not explicitly take into account the techno-economic interdependencies which influence the energy security within the energy system (Augutis et al., 2012; Glynn et al., 2017; Jansen et al., 2004; Sovacool, 2013; Vovk, Vovk, \& Lyashuk, 2017). The issue of energy security varies in the study approaches in different countries. For example, in Ukraine, it became a question of national and economic security after Russia's refusal to supply gas after March 2018 (Chernyak et. al, 2018). In the geopolitical dimension there are branches of researches that examine the global and geopolitical scope of the future international energy security and its implications for Europe and the EU-27 (Umbach (2010), Correljé \& van der Linde (2006), Gracceva \& Zeniewski (2014), Valdés Lucas et al (2016) etc.). Most authors conclude:

- There is the interlinkage between globally designed traditional energy security concepts and domestic as well as regional political stability (Umbach (2010), Correljé \& van der Linde (2006), Streimikiene \& Šivickas (2008));

- After the Russian-Ukrainian gas conflict in January 2006, the energy security has forced its way up the European energy and foreign policy agendas. The EU-27 member states have largely failed to forge a coherent European energy security and foreign policy strategy after their spring summit of 2007 because the declared political solidarity has been still lacking (Umbach (2010), European Commission (2014), Jonsson et al (2015), Maltby (2013), Austvik (2016)).

Consequently, energy security index (ESI) modeling has attracted considerable attention in recent literature. The literature review shows that various indicators and methods have been applied to measure the relationship in question. Quantifying the performance of the energy security of a country is a prerequisite for good energy policies outlining. However, the existing indices, which claim to measure energy security, have limited applicability for developing countries (Narula \& Reddy, 2016). Therefore, Sovacool (2012) defends the methods utilized in creating an energy security index. The author attempts to explain why an energy security index is needed, and then justifies research interviews as a data collection tool. Proposed by Narula \& Reddy (2016) Sustainable energy security index for developing countries is constructed using 'scores' (objective values) and 'weights' (subjective values representing trade-offs) which are then aggregated, bottom-up. An international assessment of energy security performance has been the key question in researches of Sovacool (2013), Erahman et al (2016), Radovanović et al (2017), Jansen \& Seebregts (2010), Ang et al (2015a), Glynn et al (2017) etc. Common for all these surveys is that they measure the energy security as one consisting of the interconnected factors of availability, affordability, efficiency, sustainability, and governance (accessibility, acceptability). However, the studies vary in the amount of reflecting indicators. The ESI of Radovanović et al (2017) Strielkowski (2017), for example, includes environmental and social aspects as well. The common lack of the indicated researches is that they are not universal in the geo-character and have limits in periods.

The deep glance in the nature of indices revealed that despite the appeared common features they have differences. The scope of energy security has also expanded, with a growing emphasis on dimensions such as environmental sustainability and energy efficiency. Significant differences among studies are observed in framing and construction of energy security indices (Shen et al, 2018; Jovovic et al, 2017). These variations introduce challenges in comparing the findings among studies (Ang et al, 2015b). The most strict division of existing indices is in quantifying energy security performance (i.e. a number of indicators; the scale of the index; temporal versus spatial studies; specific focused areas in index construction; energy security index construction itself; as well as normalization, weighting, aggregation etc.) and separate position is under Energy trilemma. For example, index creation methods are divided in: Normalization (min/max; distance to a reference; standardization; etc.); Weighting (equal weights; fuel/import share; PCA; AHP; DEA); Aggregation (additive aggregation, etc.). That reflects the concept of energy security that is the multitude of definitions. It can be characterized according to the sources of risk, the scope of the impacts, and the severity filters in the form of the speed, size, sustention, spread, singularity and sureness of impacts. The selection 
of conceptual boundaries along these dimensions determines the outcome and the methodology of indexes (Windzer, 2012). More clearly separating between the security of supply and other policy objectives can avoid this. Thus, there is no one ideal indicator, as the notion of energy security is highly context dependent. Rather, the applying multiple indicators lead to a broader understanding (Kruyt et al, 2009).

In 2013, Martchamadol and Kumar proposed an "Aggregated Energy Security Performance Indicator (AESPI)" that has been developed by considering 25 individual indicators representing social, economic and environmental dimensions. The principle used by authors required time series data. Researches ranged the indicators from zero to ten. The comparative advantage of AESPI is that it not only assists in knowing the past energy security status of a country but also helps in assessing the future status considering the energy policies and plans of the country, thus enabling the monitoring of the impacts of the policies (Martchamadol \& Kumar, 2013).

In 2004, a special project team (Jansen, J. C. et. al.) defined the set of indicators, which are associated with the energy supply security. Among them, import source, geopolitical stability of sources of origin, world reserves situation can be mentioned. This work provided a great examination of possible sources of energy resources. For each country, it was revealed the part of energy that is produced from solid fuels, liquid fuels, natural gas, nuclear, biomass, hydro, wind, solar, geothermal, marine energy, hydrogen, and other sources. The main stress was devoted to the diversity of different resources. Therefore, the authors used Stirling's ignorance approach or Shannon-Wiener index:

$$
S I=-\sum_{i=1}^{n} p_{i} \ln p_{i}
$$

where $p_{i}$ - the proportional representation of the $i$-th resource.

They argued that such an approach has two main features:

- Sensitivity of final ordering,

- Additivity property in case of refining the taxonomy.

At the same time, it should be noted that significant changes in economy hugely shifted measurement of energy security and, therefore, the structure of the Shannon-Wiener index should be modified. In particular, the scale of this index for maximization requires that each resource be used at about a third of the total in the country. Obviously, this can not be achieved if the country uses four or more resources. At the same time, it should be noted, that the European countries set a clear target for reducing the share of consumption of non-renewable resources. In this context, it becomes clear that such countries will gradually abandon the consumption of coal, oil, diesel and even natural gas. Already today, in the European countries, the goal is to produce at least $20 \%$ of all energy from renewable sources. However, some countries have made significant progress, guaranteeing more than 53\% of renewable energy as of 2016 (for example, in Sweden, Norway). It is obvious that under such circumstances the value of the Shannon-Wiener index for such a country will not be optimal. Table 1 represents the values of the Shannon-Wiener index for 2014 and Share of energy from renewable sources for 2014 and 2016.

It can be shown that the Shannon-Wiener index is not high in Norway. This country is characterized by massive variety of energy resources, but also by the vast introduction of clean energy technologies. Therefore, its index of 0.13 is rather misleading. Moreover, the highest index is detected for Sweden and Greece, which are relatively poor in resources.

At the same time, the share of renewable energy in the Netherlands is only $6 \%$, and the energy security index is almost 4 times higher than in Norway. In this way, the role of the energy security index should be changed, in particular, in the aspect of renewable energy sources. 
Comparison of Shannon-Wiener index with Share of energy from renewable sources

\begin{tabular}{|l|c|c|c|}
\hline \multirow{2}{*}{$\begin{array}{l}\text { GEO/TIME } \\
\text { Austria }\end{array}$} & Shannon-Index & \multicolumn{2}{c|}{ The share of energy from renewable } \\
sources
\end{tabular}

Source: Own calculations

\section{Energy security index}

As indicated earlier, the main drawbacks of different versions of energy security indices include:

1) Direct dependence on production of energy resources. In this case, resource-poor countries cannot be economically successful, but the existing examples of Japan, South Korea, and Austria tell us the opposite. At the same time, oil-rich Venezuela suffers economic crises.

2) Local prices, which were used for calculations. The question about prices is very arguable. On the one hand, all goods and services in one country are produced in local currency price level. From the other side, international prices are easier to compare. Transitional systems, like PPP, do not always provide a steady and reliable comparison. Therefore, a new index should omit using any type of prices. Resource quantities are more informative for comparison.

3) Direct comparison of indicators without taking into account changes in macroeconomic fundamentals. For example, if two neighboring countries produce significant volumes of different energy resources, then comparisons of the energy security levels of these two countries may produce false results without additional details being considered. First, how efficiently such resources are used. In addition, the possibility to exchange resources may influence the energy security.

4) Use of fossil resources that will be omitted in the nearest future. In the previous section, we gave some examples, how the European counties are going to replace all fossil resources for renewable one in the future. It means that new types of sources will be introduced, but the steady formula index may ignore changes. For example, in 2004 the level of energy from renewable sources was so dramatically low that it was not used in a consideration of the security level. Nowadays it plays one of the most important roles in all calculations.

5) Level of loses. Usually, all approaches are centered either on production or on consumption of resources, but they do not take in consideration possible loss of energy, which may be rather high in some countries.

6) Nominal values. If one country produced some amount of the energy in the previous year and increased its output by $50 \%$ this year, then security index goes up by about $50 \%$. However, in reality, it is not true. For example, if a new technology was introduced and all countries doubled output, then such increase means the diminishing. Therefore, all data must be compared with the average level. Therefore, 
everything should be normalized for the average EU level, so each change plays its role only in comparison with all modern trends.

After analyses of such drawbacks in classical approaches to the energy security index, we consider several blocks that influence the energy security of the country.

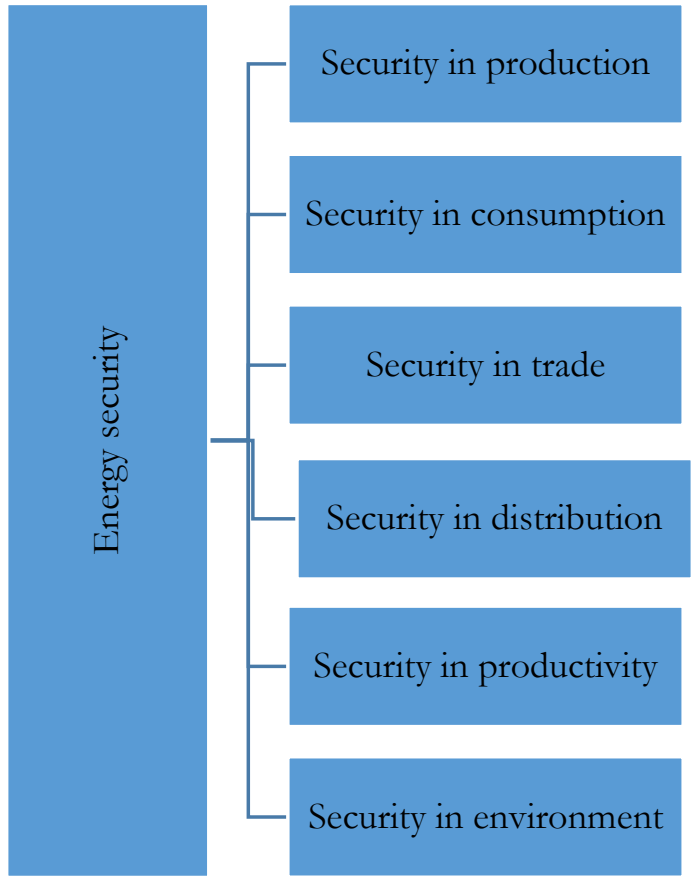

Figure 1. Structure of a new energy security index

Source: developed by authors

The first block includes the production of resources, compared to the average European level. Of course, this index may be compared to any level, not just European, but it seems logical to use this value while analyzing particularly European countries. The first block can be measured as

where

$$
I_{1}=100 \cdot \frac{E_{t}}{E_{t}^{e}}: \frac{E_{t-1}}{E_{t-1}^{e}}
$$

$E_{t}$ - Energy production in the country in period $\mathrm{t}(\mathrm{mln}, \mathrm{TOE})$,

$E_{t}^{e}-$ Energy production in the EU28 in period $\mathrm{t}(\mathrm{mln}, \mathrm{TOE})$.

Thus, the index $I_{1}$ shows how this country changes the ratio in nearest years compared to the average level. If this index is increasing, then it means that the country is developing the energy production faster than the EU, and vice versa. In this index, we especially do not divide production into parts of energy groups: solid, oil, gas, etc. It can be explained that some countries may have a natural shift of producing the energy from coal while they have vague sources of it. Other countries may use other sources instead. In any case, a certain amount of energy is produced, so the structure of fossil resources is not important in this situation.

The second index analyses the consumption of energy, compared to the average European level. As it was said before, this index may be compared to any level also, not just the European, but it seems logical to uses this value while analyzing just European countries. The index can be measured as 


$$
I_{2}=100 \cdot \frac{C_{t}^{e}}{C_{t}} \cdot \frac{C_{t-1}^{e}}{C_{t-1}}
$$

where

$C_{t}$ - Energy consumption in the country in period $\mathrm{t}(\mathrm{mln}, \mathrm{TOE})$,

$C_{t}^{e}-$ Energy consumption in the EU28 in period $\mathrm{t}(\mathrm{mln}, \mathrm{TOE})$.

Thus, the index $\mathrm{I}_{2}$ shows how this country changes the ratio of consumption in nearest years compared to the average level. If this index is increasing, then it means that the country is consuming energy faster than the EU, and controversy. As most European countries have almost the same rate of population change, the growth of this index means that the efficiency of consumption declined compared to the average European level. The consumption increase, in general, is regarded as a negative impact on the security index. However, it should primarily correspond to the European consumption trends and its previous dynamics.

The third index defines conditions of energy provision for the country. It is calculated by the formula:

$$
I_{3}=100 \frac{E_{t}+I m_{t}-E x_{t}}{E_{t}},
$$

where

$I m_{t}-$ Import of resources to the country in period $\mathrm{t}(\mathrm{mln}, \mathrm{TOE})$,

$E x_{t}-$ Export of resources from the country in period $\mathrm{t}(\mathrm{mln}, \mathrm{TOE})$.

This index indicates in what way the country satisfies its needs in the energy in period t.

The next index indicates in what way country fights with energy loses, compared to the EU level. Its formula is:

$$
I_{4}=100 \frac{L_{t}^{e}}{L_{t}}
$$

where

$L_{t}-$ Percent of the loss of energy resources in the country in period $t$,

$L_{t}^{e}-$ Percent of the loss of energy resources in the EU28 in period t.

The fifth index indicates the efficiency of using energy resources. For this index, we got productivity parameter, which measures how much USD in PPS can be produced in the country per one kg of conditional energy. Of course, this block has a drawback while using nominal currency terms, but we minimize the negative impact, normalizing this value by the average European level. Therefore, the index is written in the form:

$$
I_{5}=100 \frac{K_{t}}{K_{t}^{e}}
$$

where

$K_{t}$ - Energy productivity in the country in period t, which is measured in purchasing power standard (PPS) per kilogram of oil equivalent,

$K_{t}^{e}-$ Energy productivity in the country in period t, which is measured in purchasing power standard (PPS) per kilogram of oil equivalent.

The higher $I_{5}$ then more efficiently all energy resources are used in this country, the greater is the energy security.

The final part plays a very important role as it measures the green economy in the country. This index is calculated by the formula: 


$$
I_{6}=100 \frac{N_{t}}{N_{t}^{e}}
$$

where

$N_{t}$ - share of energy from renewable sources in the country in period $t$,

$N_{t}^{e}$ - share of energy from renewable sources in the EU28 in period $t$.

The ultimate new Energy security index is a geometric mean of indices mentioned above:

$$
N E S I=\sqrt[6]{\prod_{i=1}^{6} I_{i}}
$$

It is also very important to mention that all indices are calculated in percent and do not use nominal values. In such case, we overcome the main drawback of previous versions of ESI: the decline of oil production led to decrease of NESI, but it is not true if we replace oil with solar energy.

\section{METHODOLOGY}

\section{Data}

We used data from Eurostat for 1997-2016:

$E_{t}$ - Primary production, thousand tons of oil equivalent (TOE),

$C_{t}-$ Gross inland consumption, thousand tons of oil equivalent (TOE),

$I m_{t}-$ Imports, thousand tons of oil equivalent (TOE),

$E x_{t}-$ Exports, thousand tons of oil equivalent (TOE),

$L_{t}-$ Distribution Losses, thousand tons of oil equivalent (TOE),

$N_{t}$ - The share of energy from renewable sources (percentage).

Primarily, we used a sample of 39 European countries and 2 aggregate items (European Union with 28 countries and the Eurozone with 19 countries). For more accurate results, we dropped out countries that have missed or incomplete data. In the final sample, there are only 29 countries.

The calculation of NESI for the European countries is presented in table App.1. The graphic form can be seen in Fig. 2. The majority of countries show rather stable dynamics. There are several exceptions to this rule. First, Cyprus indicates rather a high level of security. It can be explained by the fact that Cyprus increased energy production by 20 times compared to 1990 . Such increase greatly advances average indicators in the EU. Secondly, Luxemburg increased production of energy by 5 times compared to 1990 . Majority of countries have NESI between 85 and 130 in 2016.

The rather weak performance of Lithuania (NESI=73.64 in 2016) can be explained by a dramatic decrease in energy production for the last years from 4805.5 thousand tons of oil equivalent (TOE) in 1990 until 1620.3 thousand TOE in 2016, rather immense loses of energy (as twice as vast as the EU level). However, such a significant drop in Lithuanian energy production resulted from the regulatory requirements when the largest energy producer Ignalina Nuclear Power Plant (INPP) was closed in 2009. INPP closure was orchestrated according to an agreement between Lithuania and the EU and came as a pre-requirement of accession negotiations. Nuclear energy was one of the most important contributors to Lithuanian energy security and consisted 34.6 percent of the total Lithuanian primary energy supply on average between 2000 and 2009. At the same time, the development of renewable energy in Lithuania outpaces the EU level, but it is not sufficient to restore described drops.

Among other countries, Ireland should be mentioned. It shows a great increase in NESI from 85 in 2012 to 113 in 2016 because of the rapid growth of productive consumption and development of renewable energy sources. 


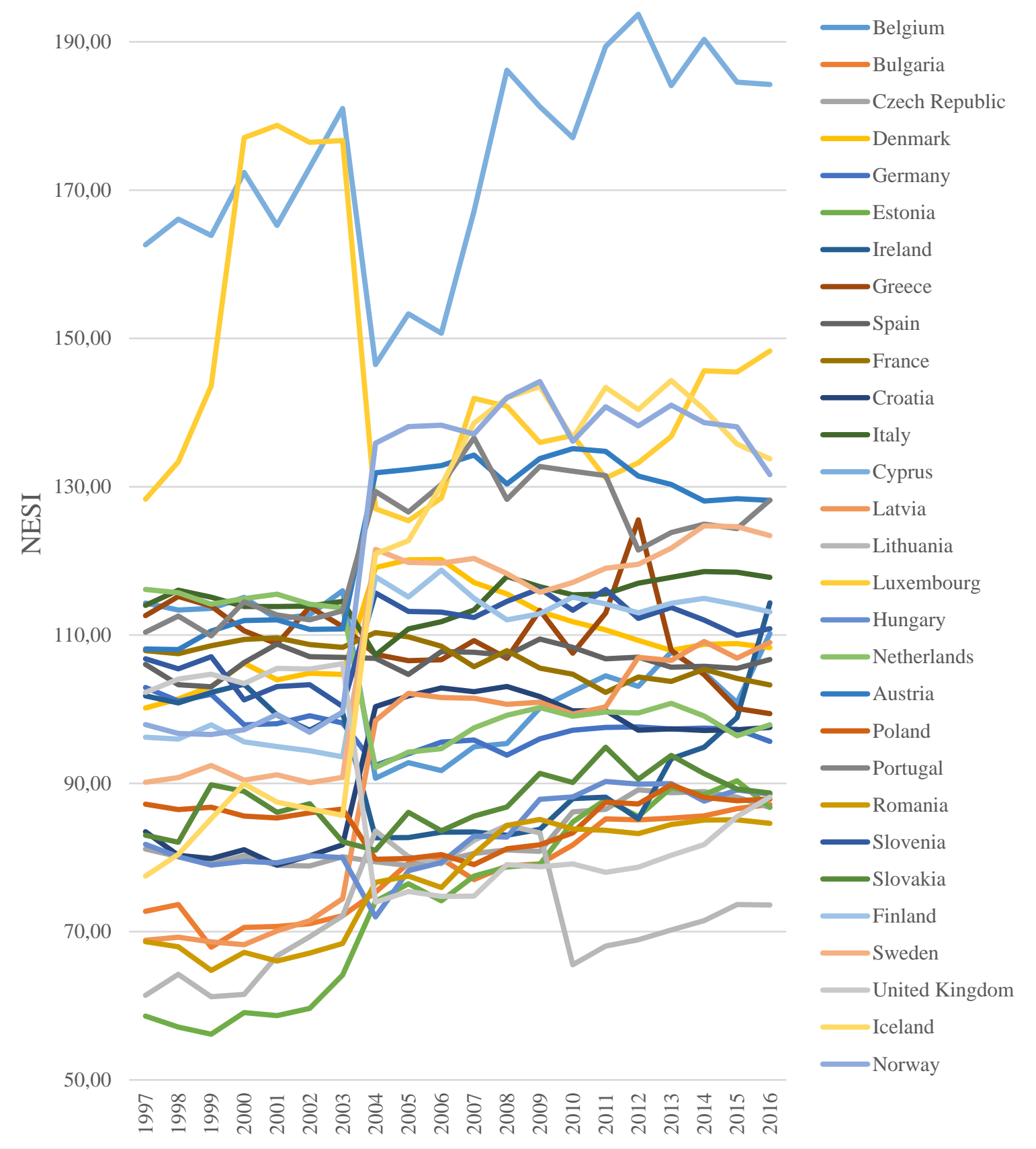

Figure 2. Dynamics of NESI in the European countries

Source: developed by authors

After analysis of NESI dynamics, we can build a model that helps us to understand, how a new index is connected to macroeconomic indicators.

\section{Methodology}

First, we present our hypotheses:

1) The greater energy security in the country, the lower the inflation index is expected. 
The rationale of such a hypothesis is the following. The higher level of energy security leads to energy prices, more closely corresponding to the global market/competitive energy prices. In such case, the energy importing country does not pay a predictive long run surcharge for monopolistic energy resource pricing schemes.

2) NESI has a positive impact on the economic growth of the country. This hypothesis seems to be discussable. NESI should positively affect growth levels in the long run, all other factors being equal. To extract the influence of ESI purely is quite problematic - other factors may influence the economy much more. For example, currently Latvia has much higher NESI level than Lithuania, but its economic growth has lagged behind since 2009 when NESI in Lithuania dropped dramatically.

3) NESI can be explained by price and growth levels in the country.

Hypothesis required new data. Therefore, we collected a series of CPI and GDP variables for all 29 countries for 1997-2016. To avoid problems with stationarity, different measurements, and unevenness of parameters, we normalized them to the average EU level and transformed by the rule:

$$
\begin{aligned}
& n C P I_{t, i}=100 \frac{C P I_{t, i}^{e}}{C P I_{t, i}}, \\
& n G D P_{t, i}=100 \frac{G D P_{t, i}}{G D P_{t, i}^{e}},
\end{aligned}
$$

where $C P I_{t, i}$ - CPI level in period $\mathrm{t}$ in the country $i$,

$C P I_{t, i}^{e}$ - CPI level in period $\mathrm{t}$ in the EU28,

$G D P_{t, i}$ - GDP level in period t in the country $i$

$G D P_{t, i}^{e}-$ GDP level in period $\mathrm{t}$ in the EU28.

For checking our hypothesis, we built three panel regressions:

$$
y_{t, i}=\beta_{0 i}+\beta_{1} X_{1 t, i}+\beta_{2} X_{2 t, i}+\varepsilon_{t, i},
$$

where

$y_{t, i}-$ the dependent variable in period $\mathrm{t}$ in country $i$,

$X_{1 t, i}, X_{2 t, i}$ - independent factors in period t in country $i$,

$\varepsilon_{t, i}$ - residuals.

As we have 580 observations, we estimate a panel regression. Of course, each country has its own specification; therefore, we used fixed effects for both time and country.

In the first model, dependent variable is nCPI, while nGDP and NESI are independent variables. For the second model, dependent variable will be nGDP, while the other two variables will be independent. Finally, in the third model, the dependent variable will be NESI, which will be explained by nCPI and nGDP. 


\section{EMPIRICAL RESULTS AND DISCUSSION}

Three models were estimated. Detailed information concerning estimation output is provided in Appendix 2. Table 2 contains aggregate estimation results.

Table 2

Estimation results

\begin{tabular}{|c|c|c|c|c|c|c|c|}
\hline \multicolumn{2}{|c|}{ Model 1 } & \multicolumn{2}{c|}{ Model 2 } & \multicolumn{2}{c|}{ Model 3 } & \multicolumn{2}{c|}{ Model 3a } \\
\hline nCPI & Coefficient & nGDP & Coefficient & NESI & Coefficient & NESI & Coefficient \\
\hline$\beta_{0}$ & 115.251 & $\beta_{0}$ & 151.554 & $\beta_{0}$ & 108.733 & $\beta_{0}$ & 107.897 \\
\hline nGDP & -0.188 & NESI & 0.134 & nGDP & 0.154 & nGDP & 0.235 \\
\hline NESI & -0.072 & CPI & -0.601 & nCPI & -0.264 & nCPI & -0.361 \\
\hline $\mathrm{R}^{2}$ & 0.945 & R2 & 0.807 & R2 & 0.850 & R2 & 0.842 \\
\hline
\end{tabular}

Source: calculated by authors

As we see, all models are significant and the coefficients are significant. Additional testing strongly rejects all hypothesis about redundant fixed effects in models 1 and 2 but does not reject for model 3 (Table App. 3). Therefore, model 3 was estimated with random effects for periods (model 3a).

From the model 1, we can conclude that there is a negative impact of NESI to CPI in the European countries. Moreover, approximately $1 \%$ increase in NESI leads to decreasing inflation in the country, comparing to the average European level approximately to $0.07 \%$.

Model 2 helps to conclude that an increase of NESI by $1 \%$ leads to an increase in GDP growth comparing to the European countries by $0.13 \%$.

Finally, model 3 with fixed effects estimates increase of NESI by $0.15 \%$ in case of nGDP growth to $1 \%$, decrease in NESI by $0.26 \%$ in case of increasing nCPI to $1 \%$. Model 3a with random effect states higher impact: increase of NESI by $0.235 \%$ in case of nGDP growth to $1 \%$, decrease in NESI by $0.36 \%$ in case of increasing nCPI to $1 \%$.

It should be reminded that the increase of nGDP for one country means that this country outruns average level in the EU28 by about 1\%. Of course, they need to guarantee the EU level first and have some additional growth.

Appendix 4 contains a fixed effect for countries based on all investigated models. Based on these data we can classify all investigated countries into several clusters (Table 3). The main idea of cluster provision is the response of countries to different parameters change. For example, cluster 0 is characterized by negative fixed effect coefficients in all three panel regressions. This cluster contains Bulgaria, Czech Republic, Hungary, and Romania. All these countries represent Eastern Europe with the transition from post-Soviet ideology. They have rather a huge impact from changing ESI to GDP and CPI factors. As these countries have restructured their economies, they can have better output growth and faster CPI change comparing to other countries. At the same time, they still have lower energy security.

The next cluster contains Greece and Slovenia, which have almost similar problems excepting relatively higher energy security index. Cluster 2 is represented by Eastern Europe countries Estonia, Latvia, Poland, and Slovakia. They have similar reactions as counties in cluster 0, but also greater GDP growth compared to neighbours.

Iceland is located quite remotely from the continental Europe and represents the cluster 3. It has negative fixed effects for CPI and GDP equations, but positive for ESI equation. It can be explained by the huge introduction of new technologies in the country for the last years. 
Clusterization of countries in the EU

\begin{tabular}{|c|c|}
\hline Cluster & Country \\
\hline \multirow{4}{*}{0} & Bulgaria \\
\hline & Czech Republic \\
\hline & Hungary \\
\hline & Romania \\
\hline \multirow{2}{*}{1} & Greece \\
\hline & Slovenia \\
\hline \multirow{4}{*}{2} & Estonia \\
\hline & Latvia \\
\hline & Poland \\
\hline & Slovakia \\
\hline 3 & Iceland \\
\hline \multirow{10}{*}{5} & Belgium \\
\hline & Denmark \\
\hline & Germany \\
\hline & France \\
\hline & Italy \\
\hline & Cyprus \\
\hline & Netherlands \\
\hline & Austria \\
\hline & Portugal \\
\hline & Norway \\
\hline \multirow{4}{*}{6} & Ireland \\
\hline & Croatia \\
\hline & Lithuania \\
\hline & United Kingdom \\
\hline \multirow{4}{*}{7} & Spain \\
\hline & Luxembourg \\
\hline & Finland \\
\hline & Sweden \\
\hline
\end{tabular}

Source: Own calculations

No counties were moved to cluster four, which is characterized by a positive fixed effect for CPI equation and negative effect for other variables. At the same time, many West European counties are located in cluster 5, which can be described by positive fixed effect for CPI and NESI equations. These countries (Belgium, Denmark, Germany, France, Italy, Cyprus, Netherlands, Austria, Portugal, and Norway) have rather a stable economy; therefore, the energy security helps to stabilize CPI, but brakes GDP growth.

Cluster 6 has rather different countries. The United Kingdom and Ireland are rather stable countries, which have positive fixed effect for CPI and GDP equation, but negative for NESI. It can be explained by the great diminishing of NESI in these countries during the last years. Croatia has rather unstable NESI, which helped to combine it with mentioned countries. This cluster contains also Lithuania, with rather low NESI. This economy is rather common to cluster two (like Latvia and Poland), but despite its neighbours, Lithuania has a positive effect in the CPI equation, representing higher inflation.

The last cluster 7 contains Spain, Luxembourg, and Scandinavian countries - Finland and Sweden. These countries have only positive fixed effects in all equations. 


\section{CONCLUSION}

This paper investigated the level of guaranteeing energy security for European countries. Despite other approaches, we focused on the index, which can explain the dynamics of any country in international comparison. All other approaches have some drawbacks with stressing on parameters of one country, ignoring immense changes worldwide. Thus, we developed a new energy security index (NESI), which is based on consumption, production, distribution, and efficient usage of energy.

It should be noted that we refused using microdata for calculating our new index. Many authors used the consumption level for every kind of fuel. This approach does not take into account technological changes that became very important in last decades. For example, countries, which produce and consume significant amounts of coal, seems to be quite successful according to the old approach, but they suffer in energy security index in a new version. The only increasing level of consumption efficiency, greater production energy from renewable sources may guarantee high places in the country ranking.

Developed NESI is a tool for authorities responsible for energy policy and academics researching energy economics. It determines the factors that change energy security balance in separate countries and larger regions (e.g. trade blocks or common energy markets). NESI precisely demonstrates when and how energy security may be affected. Thus, it could be applied in calibrating energy policy response to changes in net imports, local energy production capabilities, and regulatory or geopolitical changes.

We also investigated the question of the relationship between the newly introduced index and macroeconomic parameters in countries. Four panel regressions were estimated for the sample of existing data. It was found that all models were significant and have all required econometric characteristics. Based on them it can be concluded that the increase of GDP is positively correlated with NESI, and negatively with CPI. Therefore, on the one hand, economic tools may improve energy security in Europe, and on the other hand, guaranteeing energy security leads to lower prices and larger national output.

The application of fixed effects of mentioned regressions gave the possibility to provide clusterization of the EU countries. We revealed seven different groups of countries. It should be stressed that such grouping contains many neighbouring countries in one cluster. Eastern Europe countries are characterized by negative fixed effects in the regression for CPI, explaining lower prices in such countries. The further analysis may show that most of the neighbouring countries distinguish mainly by one parameter. For example, Norway has a different reaction to GDP growth compared with Sweden and Finland; Lithuania looks like Latvia and Poland except parameter of CPI change, etc.

The provided research helps to reveal the most valuable countries of the EU for energy security that will suffer the most in case, for example, of the destruction of the unified gas system. The application of NESI may help understand how countries react to international changes if they can support the necessary level of technological changes in the production and distribution of energy.

\section{REFERENCES}

Androniceanu, A., \& Popescu, CR. (2017). An inclusive model for an effective development of the renewable energies public sector. Administrație si Management Public, (28), 81-96.

Ang, B. W., Choong, W. L., \& Ng, T. S. (2015a). A framework for evaluating Singapore's energy security. Applied energy, 148, 314-325. https://doi.org/10.1016/j.apenergy.2015.03.088

Ang, B. W., Choong, W. L., \& Ng, T. S. (2015b). Energy security: Definitions, dimensions, and indexes. Renewable and Sustainable Energy Reviews, 42, 1077-1093. https://doi.org/10.1016/j.rser.2014.10.064

Augutis, J., Krikštolaitis, R., \& Pečiulytè, S. (2011). Lithuanian energy security level assessment based on indicator dependence. Safety and Security Engineering, IV, 71-82. Retrieved from https://www.witpress.com/Secure/elibrary/papers/SAFE11/SAFE11007FU1.pdf

Augutis, J., Krikstolaitis, R., Martisauskas, L., \& Peciulyte, S. (2012). Energy security level assessment 
technology. Applied Energy, 97, 143-149.. http://doi.org/10.1016/j.apenergy.2011.11.032

Austvik, O. G. (2016). The Energy Union and security-of-gas supply. Energy Policy, 96, $372-382$. https://doi.org/10.1016/i.enpol.2016.06.013

Chen, J., Cheng, S., Nikic, V., \& Song, M. (2018). Quo vadis? Major players in global coal consumption and emissions reduction. Transformations in Business \& Economics, 17(1), 112-132.

Chernyak, O., Kharlamova, G., \& Stavytskyy, A. (2018). Energy Perspective 2030 for Ukraine in the Context of the EU Integration. In Emerging Issues in the Global Economy (pp. 113-129). Springer, Cham. https://doi.org/10.1007/978-3-319-71876-7_10

Chuang, M. C., \& Ma, H. W. (2013). Energy security and improvements in the function of diversity indices-Taiwan energy supply structure case study. Renewable and Sustainable Energy Reviews, 24, 9-20. https://doi.org/10.1016/i.rser.2013.03.021

Correlje, A., \& Van der Linde, C. (2006). Energy supply security and geopolitics: A European perspective. Energy policy, 34(5), 532-543. https://doi.org/10.1016/i.enpol.2005.11.008

Dreyer, I., \& Stang, G. (2013). The shale gas 'revolution': Challenges and implications for the EU. EUISS Brief, 11.

Erahman, Q. F., Purwanto, W. W., Sudibandriyo, M., \& Hidayatno, A. (2016). An assessment of Indonesia's energy security index and comparison with seventy countries. Energy, 111, 364-376. https://doi.org/10.1016/i.energy.2016.05.100

European Commission. (2014). European Energy Security Strategy. European Commission Website. https://doi.org/10.1007/978-3-531-19201-7

Franki, V., \& Višković, A. (2015). Energy security, policy and technology in South East Europe: Presenting and applying an energy security index to Croatia. Energy, 90, 494-507. https://doi.org/10.1016/j.energy.2015.07.087

Glynn, J., Chiodi, A., \& Gallachóir, B. Ó. (2017). Energy security assessment methods: Quantifying the security cobenefits of decarbonising the Irish Energy System. Energy Strategy Reviews, 15, 72-88. https://doi.org/10.1016/j.esr.2016.11.005

Gracceva, F., \& Zeniewski, P. (2014). A systemic approach to assessing energy security in a low-carbon EU energy system. Applied Energy, 123, 335-348. http://doi.org/10.1016/j.apenergy.2013.12.018

Harčariková, M. \& Šoltés, M. (2016). Risk Management in Energy Sector Using Short Call Ladder Strategy. Montenegrin Journal of Economics, 12(3), 39-54.

IEA Energy Security and Climate Policy. (2007). Retrieved from https://www.iea.org/publications/freepublications/publication/energy security climate policy.pdf

Institute for 21st Century Energy. (2016). International Index of Energy Security Risk. Retrieved from https://www.globalenergyinstitute.org/sites/default/files/energyrisk intl 2016.pdf

Jansen, J. C., \& Seebregts, A. J. (2010). Long-term energy services security: What is it and how can it be measured and valued?. Energy Policy, 38(4), 1654-1664. https://doi.org/10.1016/j.enpol.2009.02.047

Jansen, J. C., Arkel, W. G. Van, \& Boots, M. G. (2004). Designing indicators of long-term energy supply security. Joop Journal of Object Oriented Programming.

Jansen, J. C., Arkel, W. V., \& Boots, M. G. (2004). Designing indicators of long-term energy supply security.

Jonsson, D. K., Johansson, B., Månsson, A., Nilsson, L. J., Nilsson, M., \& Sonnsjö, H. (2015). Energy security matters in the EU Energy Roadmap. Energy Strategy Reviews, 6, 48-56. http://doi.org/10.1016/j.esr.2015.03.002

Jovovic, R., Simanaviciene, Z., \& Dirma, V. (2017). Assessment of Heat Production Savings Resulting from Replacement of Gas with Biofuels. Transformations in Business \& Economics, 16(1) (40), 34-51.

Jun, E., Kim, W., \& Chang, S. H. (2009). The analysis of security cost for different energy sources. Applied Energy, 86(10), 1894-1901. http://doi.org/10.1016/j.apenergy.2008.11.028

Kasperowicz, R., \& Štreimikienè, D. (2016). Economic growth and energy consumption: Comparative analysis of V4 and the «old» EU countries. Journal of International Studies, 9(2), 181-194. https://doi.org/10.14254/2071$\underline{8330.2016 / 9-2 / 14}$

Kharlamova, G., Nate, S., \& Chernyak, O. (2016). Renewable energy and security for Ukraine: challenge or smart way. Journal of International Studies, 9(1), 88-115. https:// doi.org/10.14254/2071-8330.2016/9-1/7

Kruyt, B., van Vuuren, D. P., de Vries, H. J., \& Groenenberg, H. (2009). Indicators for energy security. Energy policy, 37(6), 2166-2181. https://doi.org/10.1016/j.enpol.2009.02.006. 
Lazányi, K., Virglerová, Z., Dvorský, J., \& Dapkus, R. (2017). An Analysis of Factors Related to" Taking Risks", according to Selected Socio-Demographic Factors. Acta Polytechnica Hungarica, 14(7), 35-50.

Mačerinskienė, I., \& Kremer - Matyškevič, I. (2017). Assessment of Lithuanian Energy Sector Influence on GDP, Montenegrin Journal of Economics, 13(4), 43-59.

Maltby, T. (2013). European Union energy policy integration: A case of European Commission policy entrepreneurship and increasing supranationalism. Energy policy, 55, 435-444. https://doi.org/10.1016/j.enpol.2012.12.031

Martchamadol, J., \& Kumar, S. (2013). An aggregated energy security performance indicator. Applied Energy, 103, 653670. https://doi.org/10.1016/j.apenergy.2012.10.027

Narula, K., \& Reddy, B. S. (2016). A SES (sustainable energy security) index for developing countries. Energy, 94, 326343. https://doi.org/10.1016/j.energy.2015.10.106

Radovanović, M., Filipović, S., \& Pavlović, D. (2017). Energy security measurement-A sustainable approach. Renewable and Sustainable Energy Reviews, 68, 1020-1032. https://doi.org/10.1016/j.rser.2016.02.010

Scheepers, M., Seebregts, A., de Jong, J., \& Maters, H. (2007). EU standards for energy security of supply. ECN/Clingendael International Energy Programme.

Simionescu, M., Lazányi, K., Sopková, G., Dobeš, K., \&Balcerzak, A. P. (2017). Determinants of economic growth in V4 Countries and Romania. Journal of Competitiveness, 9(1), 103-116.

Sovacool, B. K. (2012). The methodological challenges of creating a comprehensive energy security index. Energy Policy, 48, 835-840. https://doi.org/10.1016/j.enpol.2012.02.017

Sovacool, B. K. (2013). An international assessment of energy security performance. Ecological Economics, 88, 148-158. https://doi.org/10.1016/j.ecolecon.2013.01.019

Sovacool, B. K. (2013). Assessing energy security performance in the Asia Pacific, 1990-2010. Renewable and Sustainable Energy Reviews, 17, 228-247. https://doi.org/10.1016/i.rser.2012.09.031

Stavytskyy, A., Giedraitis, V., Sakalauskas, D., \& Huettinger, M. (2016). Economic crises and emission of pollutants: a historical review of select economies amid two economic recessions. Ekonomika, 95(1), 7-21.

Streimikiene, D., \& Šivickas, G. (2008). The EU sustainable energy policy indicators framework. Environment International, 34(8), 1227-1240. http://doi.org/10.1016/j.envint.2008.04.008

Streimikiene, D., Mikalauskiene, A., \& Mikalauskas, I. (2016). Comparative Assessment of Sustainable Energy Development in the Czech Republic, Lithuania and Slovakia. Journal of Competitiveness, 8(2), 31-41. https://doi.org/10.7441/joc.2016.02.03

Strielkowski, W. (2017). Social and Economic Implications for the Smart Grids of the Future. Economics and Sociology, 10(1), 310-318. https://doi.org/10.14254/2071-789X.2017/10-1/22

Šumskis, V., \& Giedraitis, V. (2015). Economic implications of energy security in the short run. Ekonomika, 94(3), 119138. https://doi.org/10.15388/Ekon.2015.3.8791

Umbach, F. (2010). Global energy security and the implications for the EU. Energy policy, 38(3), 1229-1240. https://doi.org/10.1016/j.enpol.2009.01.010

Lucas, J. N. V., Francés, G. E., \& González, E. S. M. (2016). Energy security and renewable energy deployment in the EU: Liaisons Dangereuses or Virtuous Circle?. Renewable and Sustainable Energy Reviews, 62, 1032-1046. https://doi.org/10.1016/i.rser.2016.04.069

Vovk, I., Vovk, Y., \& Lyashuk, O. (2017). Improvement of the organizational-economic mechanism of resource-saving at the machine building enterprise. Economics, Management and Sustainability, 2(2), 6-14. https://doi.org/10.14254/jems.2017.2-2.1.

Vovk, Y. (2016). Resource-efficient intelligent transportation systems as a basis for sustainable development. Overview of initiatives and strategies. Journal of Sustainable Development of Transport and Logistics, 1(1), 6-10. https://doi.org/10.14254/jsdtl.2016.1-1.1.

Winzer, C. (2012). Conceptualizing energy security. Energy Policy, 46, 36-48. https://doi.org/10.1016/i.enpol.2012.02.067.

World Energy Council World Energy Trilemma Index. (2017). Retrieved from https://www.worldenergy.org/wpcontent/uploads/2017/11/Energy-Trilemma-Index-2017-Report.pdf 


\section{APPENDIX}

\section{Appendix 1.}

Table 1

Dynamics of NESI in European countries

\begin{tabular}{|c|c|c|c|c|c|c|c|c|c|c|c|c|c|c|c|c|c|c|c|c|}
\hline $\begin{array}{l}\text { GEO/TI } \\
\text { ME }\end{array}$ & 97 & 98 & 99 & 000 & 2001 & 2002 & 2003 & 2004 & 2005 & 2006 & 2007 & 2008 & 2009 & 2010 & 2011 & 2012 & 2013 & 2014 & 2015 & 2016 \\
\hline & . & 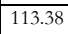 & .00 & (t) & 4 & .75 & 159 & 90.68 & 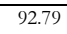 & 177 & 9 & 8 & 015 & 02.38 & 04.49 & (5) & 1 & 0 & 00.86 & 10 \\
\hline & 75 & 3.67 & 7.91 & .56 & 70.69 & 1.07 & .13 & 75.33 & .25 & 9.81 & 7.02 & 87 & 9.12 & 68 & 19 & 5.09 & 25.31 & 5.61 & 36.60 & 87.16 \\
\hline & 13 & & 4 & 24 & & 36 & 80.09 & 79.43 & 2 & 46 & 53 & 0 & 82 & 15 & 50 & 13 & 3.72 & 87 & 3.15 & 73 \\
\hline enmark & 0.16 & 1.39 & 3.09 & 6.20 & 13.96 & 4.85 & 4.70 & 119.09 & 0.13 & 20.18 & 117.09 & 15.56 & 13.19 & 111.81 & 10.69 & 09.27 & 107.91 & 108.75 & 108.83 & 108.3 \\
\hline any & 2.92 & 1.10 & 2.02 & 97.89 & 98.03 & 99.13 & 98.13 & 92.44 & 93.99 & 95.57 & 95.85 & 93.79 & 96.00 & 97.15 & 97.54 & 97.62 & 97.32 & 97.45 & 97.28 & 95.65 \\
\hline & .62 & 57.13 & 56.17 & 59.07 & 58.67 & 59.63 & 64.16 & 74.08 & 76.45 & 74.16 & 77.49 & 78.71 & 79.07 & 84.78 & 87.81 & 85.51 & 89.41 & 88.48 & 90.34 & 86.78 \\
\hline Irela1 & 1.79 & $\overline{00.86}$ & 102.26 & 103.38 & 99.20 & 97.15 & 99.54 & 82.66 & 82.70 & 83.41 & 83.44 & 83.00 & 83.78 & 87.95 & 88.12 & 85.20 & 93.32 & 94.88 & 98.87 & 114.34 \\
\hline Greece & 2.62 & 5.21 & 3.92 & 0.56 & 108.82 & 13.78 & 111.13 & 107.39 & 06.55 & 106.68 & 109.26 & 06.85 & 113.33 & 107.55 & 112.95 & 125.53 & 107.92 & 104.65 & 100.10 & 99.40 \\
\hline Spair & 6.03 & 3.30 & 103.02 & 6.29 & 08.77 & 77.07 & 106.97 & 106.87 & 104.68 & 07.76 & 107.67 & 107.25 & \begin{tabular}{|l|l|}
109.46 \\
\end{tabular} & 108.34 & 106.78 & 107.01 & 105.67 & 105.78 & 05.50 & \begin{tabular}{|l|}
106.69 \\
\end{tabular} \\
\hline$F_{1}$ & 7.90 & 7.48 & 8.57 & 9.40 & 99.61 & 8.72 & 8.34 & 0.33 & 09.75 & 88.48 & 105.73 & 07.90 & 105.52 & 104.73 & 02.26 & 04.34 & 103.73 & 105.38 & 04.14 & 103.2 \\
\hline Croat & 83.48 & 80.29 & 79.87 & 81.04 & 78.97 & 80.25 & 81.72 & 100.33 & 01.79 & \begin{tabular}{|l|}
102.85 \\
\end{tabular} & 102.37 & 103.06 & 101.69 & 99.78 & 99.81 & 97.17 & 97.36 & 97.12 & 97.21 & 97.55 \\
\hline Italy & 3.99 & $\overline{16.06}$ & 115.10 & 113.85 & 113.83 & 13.91 & 114.53 & 107.29 & 110.82 & 1111.80 & 113.38 & 117.91 & 116.51 & 115.42 & 115.55 & 117.00 & 117.78 & 118.56 & 118.46 & 117.76 \\
\hline & 2.61 & 66.08 & 33.90 & 172.38 & 165.23 & 73.06 & 80.99 & 146.48 & 53.31 & 150.69 & 167.15 & 186.18 & 181.26 & 177.07 & 189.37 & 193.71 & 184.08 & 190.33 & 84.57 & 184.2 \\
\hline & 8.84 & 69.24 & 68.62 & 68.24 & 70.09 & 71.49 & 74.43 & 98.45 & 102.13 & 101.58 & 101.49 & 00.65 & 100.93 & 99.34 & 100.30 & 106.99 & 106.58 & 109.13 & 106.87 & 109.00 \\
\hline Lith & 61.40 & 64.24 & 61.22 & 61.54 & 66.73 & 69.30 & 72.11 & 83.56 & 80.12 & 79.17 & 82.30 & 84.36 & 83.30 & 65.52 & 68.06 & 68.89 & 70.22 & 71.48 & 73.64 & 73.61 \\
\hline Lux & 8.31 & 133.37 & 143.60 & 07 & 3 & 85 & & 14 & & & & & 97 & & 19 & 22 & & 62 & 46 & \\
\hline & 76 & 10 & 8.96 & 49 & 28 & 0.22 & 99 & .98 & 8.23 & .32 & 82.86 & 2.74 & 7.85 & 88.18 & 0.25 & 9.90 & 89.95 & 37.59 & 99.11 & 88.5 \\
\hline $\mathrm{Ne}$ & 6.15 & 5.69 & 14.15 & 4.90 & 15.51 & 4.17 & 13.64 & 92.13 & 94.21 & 94.66 & 97.49 & 99.18 & 00.20 & 99.07 & 99.62 & 99.50 & 100.78 & 99.08 & 96.40 & 97.8 \\
\hline & 8.11 & 3.04 & 0.55 & 1.96 & 2.05 & 0.77 & 0.84 & 1.87 & 2.32 & 2.85 & 8.26 & 30.37 & 33.80 & 5.13 & 34.7 & 31.43 & 30.30 & 28.07 & 28.40 & 128. \\
\hline & 7.18 & 86.45 & 86.77 & 85.59 & 85.33 & 86.03 & 86.53 & 79.75 & 79.84 & 80.39 & 79.04 & 81.18 & 81.72 & 83.30 & 87.48 & 87.22 & 89.81 & 88.11 & 87.64 & 87.88 \\
\hline & 0.37 & 112.55 & 109.89 & 114.47 & 112.71 & 112.05 & 113.29 & 129.35 & 126.60 & 130.31 & 136.59 & 128.29 & 132.74 & 132.11 & 131.49 & 121.47 & 123.83 & 124.94 & 124.35 & 128.18 \\
\hline & 68.64 & 67.96 & 64.77 & 67.20 & 66.05 & 67.10 & 68.39 & 76.64 & 77.49 & 75.96 & 80.50 & 84.33 & 85.13 & 83.85 & 83.65 & 83.23 & 84.46 & 85.06 & 85.07 & 84.61 \\
\hline & 6.80 & 105.43 & 107.09 & 101.25 & 103.06 & 103.29 & 100.38 & 115.68 & 113.18 & 113.08 & 112.36 & 114.53 & 116.25 & 113.33 & 116.13 & 112.23 & 113.71 & 112.03 & 109.96 & 110.84 \\
\hline & 82.99 & 82.07 & 89.81 & 88.92 & 86.10 & 87.26 & 82.11 & 80.98 & 86.09 & 83.59 & 85.59 & 86.81 & 91.34 & 90.10 & 94.87 & 90.57 & 93.78 & 91.30 & 89.22 & 88.69 \\
\hline & 6.22 & 95.97 & 97.87 & 95.59 & 94.96 & 94.41 & 93.57 & 117.85 & 115.13 & 18.75 & 114.94 & 112.04 & 112.86 & 115.09 & 114.18 & 113.00 & 114.28 & 114.95 & 114.10 & 113.13 \\
\hline & 14 & 90.79 & 92.41 & 90.42 & 91.14 & 90.08 & 90.79 & 121.56 & 119.78 & 1119.70 & 120.34 & 118.29 & 115.77 & 117.08 & 118.99 & 119.55 & 121.72 & 124.73 & 124.61 & 123.42 \\
\hline United & 22.27 & 04.04 & 104.71 & 103.46 & 105.51 & 05.41 & 106.13 & $\begin{array}{l}73.97 \\
\end{array}$ & 75.42 & 74.76 & 74.78 & 79.04 & 78.76 & 79.12 & 78.00 & 78.70 & 80.30 & 81.74 & 85.51 & 88.13 \\
\hline & 1.10 & 00.47 & 03.24 & 893 & 87.46 & 00.00 & 0.00 & 20.96 & 22.71 & 0.22 & 8.58 & 41.98 & 3.51 & 6.56 & 43.41 & 40.41 & 4.32 & 140.45 & 35.74 & 33.77 \\
\hline orway & 97.92 & 96.71 & 96.59 & 97.24 & 99.30 & 96.87 & 99.61 & 135.88 & 138.12 & 138.29 & 137.10 & 142.01 & 144.19 & 136.13 & 140.79 & 138.21 & 141.01 & 138.64 & 138.08 & 131.62 \\
\hline
\end{tabular}




\section{Appendix 2.}

Model 1 estimation output

Dependent Variable: CPI

Method: Panel Least Squares

Date: 03/18/18 Time: 18:36

Sample: 19972016

Periods included: 20

Cross-sections included: 29

Total panel (balanced) observations: 580

\begin{tabular}{crrrr}
\hline Variable & Coefficient & Std. Error & t-Statistic & Prob. \\
& & & & \\
C & 115.2506 & 3.111204 & 37.04372 & 0.0000 \\
GDP & -0.187561 & 0.022851 & -8.208098 & 0.0000 \\
ESI & -0.071715 & 0.022431 & -3.197119 & 0.0015 \\
\hline
\end{tabular}

Effects Specification

Cross-section fixed (dummy variables)

Period fixed (dummy variables)

R-squared

Adjusted R-squared

S.E. of regression

Sum squared resid

Log-likelihood

F-statistic

Prob(F-statistic)
0.944602

0.939480

5.097829

13773.57

$-1741.553$

184.4304

0.000000
Mean dependent var

S.D. dependent var

Akaike info criterion

Schwarz criterion

Hannan-Quinn criteria.

Durbin-Watson stat
86.58910

20.72220

6.177769

6.553893

6.324408

0.154456 
Model 2 estimation output

Dependent Variable: GDP

Method: Panel Least Squares

Date: 03/18/18 Time: 18:16

Sample: 19972016

Periods included: 20

Cross-sections included: 29

Total panel (balanced) observations: 580

$\begin{array}{crrrr}\text { Variable } & \text { Coefficient } & \text { Std. Error } & \text { t-Statistic } & \text { Prob. } \\ & & & \\ \text { C } & 151.5539 & 8.248730 & 18.37300 & 0.0000 \\ \text { ESI } & 0.133875 & 0.040129 & 3.336089 & 0.0009 \\ \text { CPI } & -0.601309 & 0.073258 & -8.208098 & 0.0000\end{array}$

Effects Specification

Cross-section fixed (dummy variables)

Period fixed (dummy variables)

R-squared
Adjusted R-squared
S.E. of regression
Sum squared resid
Log-likelihood
F-statistic
Prob(F-statistic)

0.807287

0.789470

9.127738

44157.27

$-2079.405$

45.31016

0.000000
Mean dependent var

S.D. dependent var

113.3159

Akaike info criterion

19.89325

Schwarz criterion

7.342776

Hannan-Quinn criteria.

7.718899

Durbin-Watson stat

7.489414

0.170109 
Model 3 estimation output

Dependent Variable: ESI

Method: Panel Least Squares

Date: 03/18/18 Time: 18:16

Sample: 19972016

Periods included: 20

Cross-sections included: 29

Total panel (balanced) observations: 580

\begin{tabular}{crrrr}
\hline Variable & Coefficient & Std. Error & t-Statistic & Prob. \\
& & & & \\
C & 108.7332 & 10.27162 & 10.58578 & 0.0000 \\
GDP & 0.153630 & 0.046051 & 3.336089 & 0.0009 \\
CPI & -0.263839 & 0.082524 & -3.197119 & 0.0015 \\
\hline
\end{tabular}

Effects Specification

Cross-section fixed (dummy variables)

Period fixed (dummy variables)

R-squared

Adjusted R-squared

S.E. of regression

Sum squared resid

Log-likelihood

F-statistic

Prob(F-statistic)
0.849527 Mean dependent var

0.835615 S.D. dependent var

9.778020 Akaike info criterion

50673.13

$-2119.320$

61.06578

0.000000
Schwarz criterion

Hannan-Quinn criteria.

Durbin-Watson stat
103.2963

24.11682

7.480414

7.856537

7.627052

0.393333 
Appendix 3.

Redundant Fixed Effects Tests

Model 1

\begin{tabular}{lrrr}
\hline Effects Test & Statistic & d.f. & Prob. \\
\hline & & & \\
Cross-section F & 255.081325 & $(28,530)$ & 0.0000 \\
Cross-section Chi-square & 1550.045203 & 28 & 0.0000 \\
Period F & 4.217957 & $(19,530)$ & 0.0000 \\
Period Chi-square & 81.671753 & 19 & 0.0000 \\
Cross-Section/Period F & 157.203442 & $(47,530)$ & 0.0000 \\
Cross-Section/Period Chi-square & 1568.370964 & 47 & 0.0000 \\
\end{tabular}

Model 2

\begin{tabular}{lrrr}
\hline Effects Test & Statistic & d.f. & Prob. \\
\hline & & & \\
Cross-section F & 64.007128 & $(28,530)$ & 0.0000 \\
Cross-section Chi-square & 856.888001 & 28 & 0.0000 \\
Period F & 4.565516 & $(19,530)$ & 0.0000 \\
Period Chi-square & 87.915429 & 19 & 0.0000 \\
Cross-Section/Period F & 43.231158 & $(47,530)$ & 0.0000 \\
Cross-Section/Period Chi-square & 913.855867 & 47 & 0.0000 \\
\end{tabular}

Model 3

\begin{tabular}{lrrr}
\hline Effects Test & Statistic & d.f. & Prob. \\
& & & \\
& & & \\
Cross-section F & 83.759681 & $28,530)$ & 0.0000 \\
Cross-section Chi-square & 980.794632 & $(19,530)$ & 0.0000 \\
Period F & 1.376116 & 19 & 0.1322 \\
Period Chi-square & 27.929440 & $(47,530)$ & 0.0848 \\
Cross-Section/Period F & 54.406968 & 47 & 0.0000 \\
Cross-Section/Period Chi-square & 1022.029202 & & \\
\end{tabular}


Model 3a

Effects Test

Cross-section $\mathrm{F}$

Cross-section Chi-square
Statistic

89.230694

994.099762 d.f

Prob.

\section{Appendix 4.}

Cross-section fixed effects

\begin{tabular}{|c|c|c|c|c|}
\hline Country & Model 1 & Model 2 & Model 3 & Model 3a \\
\hline Belgium & 11.65 & -4.61 & 7.17 & 9.57 \\
\hline Bulgaria & -22.13 & -12.04 & -29.69 & -31.31 \\
\hline Czech Republic & -4.62 & -5.82 & -19.94 & -19.50 \\
\hline Denmark & 10.79 & -9.02 & 12.47 & 15.10 \\
\hline Germany & 14.35 & -8.52 & 2.11 & 5.60 \\
\hline Estonia & -8.71 & 24.66 & -36.39 & -39.83 \\
\hline Ireland & 15.50 & 51.39 & -14.95 & -17.91 \\
\hline Greece & -0.78 & -10.49 & 8.12 & 9.00 \\
\hline Spain & 6.34 & 0.28 & 5.54 & 6.47 \\
\hline France & 14.52 & -4.79 & 10.20 & 13.05 \\
\hline Croatia & 6.55 & 3.62 & -7.71 & -6.76 \\
\hline Italy & 7.32 & -19.31 & 18.34 & 21.41 \\
\hline Cyprus & 12.20 & -6.42 & 72.53 & 73.37 \\
\hline Latvia & -4.95 & 23.66 & -18.29 & -21.47 \\
\hline Lithuania & 3.41 & 31.91 & -35.34 & -37.53 \\
\hline Luxembourg & 14.78 & 12.23 & 41.95 & 41.90 \\
\hline Hungary & -34.05 & -22.49 & -27.31 & -29.86 \\
\hline Netherlands & 9.09 & -1.61 & 4.42 & 6.09 \\
\hline Austria & 15.32 & -5.26 & 27.02 & 29.58 \\
\hline Poland & -15.62 & 8.75 & -25.61 & -28.68 \\
\hline Portugal & 6.70 & -12.18 & 23.80 & 25.76 \\
\hline Romania & -80.52 & -50.13 & -45.58 & -52.52 \\
\hline Slovenia & -15.52 & -9.20 & 2.21 & 0.50 \\
\hline Slovakia & -16.24 & 7.26 & -22.94 & -26.01 \\
\hline Finland & 15.53 & 7.70 & 8.84 & 10.41 \\
\hline Sweden & 16.88 & 4.20 & 12.18 & 14.31 \\
\hline United Kingdom & 11.75 & 2.17 & -10.18 & -8.07 \\
\hline Iceland & -2.25 & 7.03 & 11.57 & 10.00 \\
\hline Norway & 12.69 & -2.97 & 25.45 & 27.32 \\
\hline
\end{tabular}

